\title{
Minapadi-Sri Pattern on Rice Cultivation with IR42 Varieties
}

\section{Nalwida Rozen, Aswaldi Anwar, dan Nilla Kristina}

\author{
Agrotechnology Study Program, Faculty of Agriculture Andalas University, Indonesia \\ Email: rozennalwida@agr.unand.ac.id \\ Agrotechnology Study Program, Faculty of Agriculture Andalas University, Indonesia \\ Email : alohaswaldi@gmail.com
}

\begin{abstract}
Food needs of Indonesia's population is still dominated by rice. Meanwhile, the conversion of irrigated rice fields seems unstoppable. This fact should be addressed by policy and the application of technology for rice production so that it is still possible to meet the national food need while increasing the income of rice farmers. The experiment on Minapadi-SRI pattern of rice cultivation with variety IR42 conducted. SRI (the system of rice intensification) is the formation of phyllochron 12 times and many phytomers. The experiment was conducted from April to September 2017 at Sungai Bangek village, Balai Gadang, Koto Tangah, Padang, West Sumatera. The objective of the study was to get the best technology for food production which is profitable. A Randomized Block Design with split plots was used with two water levels $(20 \mathrm{~cm}$ and 10 $\mathrm{cm})$ and three trench widths $(50 \mathrm{~cm}, 75 \mathrm{~cm}$ and $100 \mathrm{~cm})$. Data were analyzed using the $F$ test at the $5 \%$ level and the Honest Significant Difference test at the 5\% level. Observation of the yield and yield components of rice crops; height of plants, number of tiller/clump, number of productive tiller/clump, panicle length, number of grains/panicle, number of pithy rice/panicles, weight of 1000 grains, and yield/plot were made. The result of this research is that $10 \mathrm{~cm}$ inundation with $50 \mathrm{~cm}$ wide trenches are better for rice plant growth and yield/plot.
\end{abstract}

Keywords - Appropriate technology, Minapadi, SRI, transformation of land, yield.

\section{INTRODUCTION}

Rice is the staple diet of the Indonesina and most people in the world. National rice needs every year continue to increase as the population increases, on the other hand the area of rice fields cultivations continues to decrease for varous reasons. Various efforts to increase production have been implemented both through extensification and intensification. According to the Central Bureau of Statistics of rice production (kiloton) in Indonesia, was: 71,280 in $2013 ; 70,846$ in $2014 ; 75,398$ by $2015 ; 79,355$ in 2016; and 81,382 by 2017 .

Efforts to increase food production embodied in the Tujuh Gema Revitalitas Pertanian are: 1) Land Revitalization; 2) Revitalization of Seedlings; 3) Revitalization of Infrastructure and Facilities; 4) Revitalization of Human Resources; 5) Revitalization of Farmers Finance; 6) Revitalization of Farmer's Institutions; and 7) Revitalization of Downstream Technology and Industry (Nuryati et al., 2015). Various efforts to increase production have been implemented both through intensification (which is the best cultivation of agricultural land by utilizing existing facilities, for example: the use of purple seeds, the use of fertilizers, the use of irrigation and so on) or extensification (opening up new farmland).

One of the efforts of the last decade to give hope is the application of SRI (System of Rice Intensification) in rice cultivation. Various research reports and farmers' cultivation results show an increase in yields of up three fold. SRI is a method in rice cultivation that has the potential to increase rice productivity by changing the planting system, plant spacing, water delivery, and fertilizer use. Barkelaar (2001) stated that the advantages of rice cultivation with the SRI method include: watersaving, being cost-effective, time-saving, saving seed, being environmentally friendly, and increased production. With the SRI method tillers production double, because with this method phyllocron is formed up to 12 times. Phyllochron is something circuit Phytomer formed for 35 days depends on temperature (Bakelaar, 2002). The phyllochron is affected by temperature, time of seedling transfer and nursery methods (Veeramani et al., 2012). The most suitable rice fields for SRI development are irrigated rice fields whose water availability is more secure. The water does not need to flood the entire surface of the rice field, just enough to ensure the soil remains saturated (around field capacity). 
The crops' microenvironment will be crucially influenced by the agronomic management practies, setting in motion important interactions. For example, the water management regime will affect soil aeration, the soil microbial communities, the organic matter mineraliation process, and as a result the dynamics and availability of soil nutrients. It will also affect the build-up of various insect pests, diseases and weeds (Stoop et al., 2002). SRI will be defined technically by key practices (principles) mentioned above, but not a fixed package to be followed strictly. Even though only a part of key practices is adopted, it can be considered as SRI as far as SRI effects appear.

Kasli and Effendi's (2011) study provides hope for furture modofication of the SRI system. They reported that the best results with potted plants were obtained with water about $10 \mathrm{~cm}$ from the surface. Rice could planted in the surface layer part and enough water provided in a trench between the rice plots. This means it is sufficient for water to remains in the trench between plots rice from planting until close to harvest. If rice plants are about 100 days old of planting, then there would be a puddle for about 80 days. Sufficient time to growth fish in the waterh.

SRI among the methods has an edge over other water saving methods as water saving does not have a yield penalty in this system. Therefore, efforts are being made in many countries to popularize SRI to overcome the challenges of water shortages. System of rice intensification management purpose the use of single young seedling raised in raised bed under aerobic conditions, drastically reduced plant densities (16 hills $/ \mathrm{m}^{2}$ ), keeping fields unflooded and use of a mechanical weeder which aerates the soil and use of more organic manures, all the practices with the aim of providing optimal growth conditions for the plant, to get better performance in terms of yield and input productivity. SRI has been promoted for more than a decade as a set of organic management practices for rice cultivation that enhances the yield and reduce water requirements (Satyanarayana et al., 2005 cit Kumar et al., 2013).

Farmer's in some areas of Indonesia usually use water in their rice fields to keep fish, either directly among the flooded rice clumps or by making a special plot in the middle or on the edge of their rice fields, or by alternating fish farminge with rice planting. This cultivation method is known as minapadi.West Sumatra is one of the areas where farmers are used to doing this. Ramli (2010) reported that in Kabupaten Lima Puluh Kota about 150 ha of rice fields are used for minapadi.
Farmer's are in the habit of flooding the fields continuously from when the seed is planted until the plants close to harvest time, both in the rainy season and the dry season. To solve the problem, there needs to be technological improvements at the farm level to improve the efficiency of water use, such as an appropriate water management ystem. Generally, plant spacing and flooding time is known to have an effect on the growth and yield of rice.

Combining SRI with minapadi is possible. The merger is a form of product diversification. But some issues still need to answered so that application at the farm level is more practical, scientifically accountable and profitable not only for farmers' incomes, but also nationally beneficial because it can play a role in strengthening food security. Rozen et al., (2011) studied minapadi-SRI in paddy fields with tilapia fish and this can increase farmer's income, but they did have not study the best depth of water is profitable for fish life in the trench. Intensification of rice minapadi is one aspect of fish farming in rice fields. Rice farming is an agricultural activity that combines fish farming with rice field cultivation. According to Dio denha (2011), the minapadi farming system is not new since it has been used since the 1950-1960s but the profit earned is still low. This is because the cultivation technique is still simple (traditional) and diverse. Farming fish in the rice fields is one way to improve the efficiency of land use.

Some of these problems can be formulated as follows: if SRI rice cultivation is coupled with fish farming what depth of water in the trench is most advantageous for both, what is the most appropriate trench width, what type of fish is most profitable, what is good management, how should the products be processed and marketed. These questions need answers that can be justified. For this reason the research described below was conducted.

In general, this study aims to increase the value of irrigated rice fields, whose area is believed to be shrinking, while still producing rice as the main national food in addition to the producing products such as fish. Although some rice fields are used for fish maintenance, this will not interfere with the production of rice because the SRI system yields 2-3 times the national average, rather additional income from fish will benefit farmers. Even more so, if the fish produced are used to make processed foods like babyfish by adding a particular flavor, perhaps chili babyfish, babyfish, rendang flavoured and so on.

The most beneficial combination between water and trench width on SRI rice cultivation with minapadi, hereinafter abbreviated as MINAPADI-SRI was 
determined. Combinations of varieties and types of fish that are most profitablye cultivated/processed were examined. The results of this sort of study this sort of study are often not well explained to the target community so outcomes are often forgotten ends. Therefore, Banda Langik farmer's group was involved as a partner, to try and guarantee continue the application of MINAPADI-SRI and possibly its introduction to other areas.

\section{MATERIAL AND METHOD}

Field trials were conducted on land farmerd by members of the Banda Langik, Sungai Bangek, Koto Tangah, Padang from April- September 2017. The farmers were already using the SRI. A Split Plot Random Group divided plot design with two factors and three groups was used. Ditches were either $50 \mathrm{~cm}, 75 \mathrm{~cm}$, or $100 \mathrm{~cm}$ wide (main factor) and contained either $10 \mathrm{~cm}( \pm 2 \mathrm{~cm}), 20 \mathrm{~cm}$ $( \pm 2 \mathrm{~cm})$ of water (subplot factor). Data were analyzed using the $\mathrm{F}$ test at the $5 \%$ level. Benchmarking value middle treatment use Median values were tested using Turkey's Honest Significant Difference test also at the $5 \%$ level..

Processing of land done by handtraktor 2 times then left for a week, made a plot of 18 plots with the size of each ran $1 \mathrm{~m} \mathrm{x} 12 \mathrm{~m}=12 \mathrm{~m}^{2}$. After that made the channel as wide as $50 \mathrm{~cm}, 75 \mathrm{~cm}$, or $100 \mathrm{~cm}$ then water is grabbed as high as $10 \mathrm{~cm}$ and $20 \mathrm{~cm}$. IR42 rice seedlings planted 15 days after seedling 1 seeds per planting holes with spacing $25 \mathrm{~cm} \times 25 \mathrm{~cm}$. fertilization is done by giving urea $200 \mathrm{~kg} / \mathrm{ha}$, TSP $100 \mathrm{~kg} / \mathrm{ha}, \mathrm{KCl} 100 \mathrm{~kg} / \mathrm{ha}$. KCl and TSP are well matched at planting time along with a thirdquarter urea. Giving urea second and third age 21 days and 42 days after planting. Weeding done in 10 days after planting and next done 21 days after panting with manually. Water regulation is done during vegetative not stagnant. Enter the generative phase of the land is flooded until 20 days before harvest.

For rice plants (variety IR42) the following data collected: high plant, number of tillers, number of productive tillers, length of the panicle, weight of 1000 grains, the number of grains per panicle, the number of unhulled grains per panicle, yield of grain per panicle and per plot from which the yield (dry weight was calculated). While for fish, the data collected was their initial and final weight.

\section{RESULTS AND DISCUSSION}

Plant height at 63 days after planting for different depths of water and channel widths are shown in Table 1. Only the depth of water showed a significant difference. The deeper water gave taller plants perhaps because of better soil moisture levels. The was no interaction between water depth and channel width, and no significant effect of channel width on plant height.

Table 1. Plant Height at 63 days after planting

\begin{tabular}{|c|c|c|c|c|}
\hline \multirow{2}{*}{$\begin{array}{c}\text { Depth of } \\
\text { water in } \\
\text { the } \\
\text { channel }\end{array}$} & \multicolumn{3}{|c|}{ Water channel width } & \multirow{2}{*}{ Average } \\
\cline { 2 - 4 } & $50 \mathrm{~cm}$ & $75 \mathrm{~cm}$ & $100 \mathrm{~cm}$ & \\
\hline $10 \mathrm{~cm}$ & 66.56 & 66.06 & 64.78 & $65.80 \mathrm{~b}$ \\
\hline $20 \mathrm{~cm}$ & 76.61 & 71.00 & 72.39 & $73.33 \mathrm{a}$ \\
\hline Average & 71.59 & 68.53 & 68.59 & \\
\hline
\end{tabular}

Numbers in the same column followed by the same lower case letters are not significantly different, Tukey's Honest Significant Difference test at the 5\% level

In the SRI method, the humid state will make the soil aeration better so that sufficient oxygen will be available in the soil for root growth and development. The roots will be healthy so that the aerial parts of the plant will also be healthy. According to Kawano et al., (2009) inundation will spur stem elongation as an escape strategy against flooding to help meet the need for oxygen and carbon dioxide to support aerobic respiration and photosynthesis

The total number of tillers is shown in Table 2. No significsnt differences were found.

Table 2. Number of tillers at 63 days after planting

\begin{tabular}{|c|c|c|c|c|}
\hline \multirow{2}{*}{$\begin{array}{l}\text { Depth of } \\
\text { water in } \\
\text { the } \\
\text { channel }\end{array}$} & \multicolumn{3}{|c|}{ Water channel width } & \multirow[b]{2}{*}{ Average } \\
\hline & $50 \mathrm{~cm}$ & $75 \mathrm{~cm}$ & $100 \mathrm{~cm}$ & \\
\hline $10 \mathrm{~cm}$ & 45.39 & 47.61 & 55.00 & 49.33 \\
\hline $20 \mathrm{~cm}$ & 46.28 & 43.83 & 47.17 & 45.76 \\
\hline Average & 45.84 & 45.72 & 51.09 & \\
\hline
\end{tabular}

significantly different $F$ test at the $5 \%$ level

The formation of tillers is influenced by the SRI method because in this method the seedlings are planted early to increase the number of tillers formed and phyllochron will be formed up to 12 times. In the third phyllochron will form a multiply tillers. Supported by Bakelaar (2002) report that with the SRI method the number of tillers will double, because the phyllocron formed up to 12 times.

Rozen et al., (2017) states that from rod main varieties of Batang Piaman SRI method formation puppies on phyllchron both of which amounted to 1 tillers. On puppies first formed again puppies start phyllochron to 4 to 9 with the number of 6 tillers. On puppies secondary 
formed puppies start phyllochron to 7 to 12 with amount tillers 14 cigarettes. On puppies third formed puppies start phyllochron to 8 to 12 with the number of 14 stems. While from puppies to four formed puppies star phyllochron to 10 to 12 amounted to 4 tillers. On puppies fifth appear puppies on phyllochron to 12 as many as 1 bar. Total tillers are erratic as many as 40 stems.

The number of productive tillers is related to the total number of tillers, the more tillers formed the more productive tillers. With respect to number of productive tillers no interaction and no significant differences were observed (Table 3 ).

Table 3. Number of productive tillers

\begin{tabular}{|c|c|c|c|c|}
\hline \multirow{2}{*}{$\begin{array}{l}\text { Depth of } \\
\text { water in } \\
\text { the } \\
\text { channel }\end{array}$} & \multicolumn{3}{|c|}{ Water channel width } & \multirow[b]{2}{*}{ Average } \\
\hline & $50 \mathrm{~cm}$ & $75 \mathrm{~cm}$ & $100 \mathrm{~cm}$ & \\
\hline $10 \mathrm{~cm}$ & 28.67 & 34.11 & 31.56 & 31.45 \\
\hline $20 \mathrm{~cm}$ & 30.61 & 31.50 & 27.28 & 29.80 \\
\hline Average & 29.64 & 32.80 & 29.42 & \\
\hline
\end{tabular}

significantly different $F$ test at the 5\% level

As expected for the SRI system more productive tillers were formed compared with conventional methods (average 16-20 stems) because of the early transfer of seedlings. Increased number of tillers is, among others, due to increased nitrogen uptake during the vegetative phase (Ded atta, 1981). Flooding treatment in early rice growing increases the number of saplings. This is in the opinion of Vergara (1976), that the need for water for rice plants at the beginning of the vegetative phase is critical, where the vegetative phase is the phase of the formation of the active tiller and the maximum tiller.

No interaction and no significant differences in the length of the panicle were found (Table 4).

Table 4. Panicle length $(\mathrm{cm})$

\begin{tabular}{|c|c|c|c|c|}
\hline \multirow{2}{*}{$\begin{array}{c}\text { Depth of } \\
\text { water in } \\
\text { the } \\
\text { channel }\end{array}$} & $50 \mathrm{~cm}$ & $75 \mathrm{~cm}$ & $100 \mathrm{~cm}$ & \multirow{2}{*}{ Average } \\
\cline { 2 - 5 } & & 27.38 & 27.69 & 27.75 \\
\hline $10 \mathrm{~cm}$ & 28.17 & 28.04 & 28.04 & 27.64 \\
\hline $20 \mathrm{~cm}$ & 26.84 & 27.71 & 27.87 & \\
\hline Average & 27.51 & 27.87 & are not \\
\hline
\end{tabular}

significantly different $F$ test at the $5 \%$ level

No interactions and no significant differences in either the number of grains or the number of filled grains per panicle were found (Table 5 and 6).
Table 5. Number of grains per panicle

\begin{tabular}{|c|c|c|c|c|}
\hline $\begin{array}{c}\text { Depth of } \\
\text { water in } \\
\text { the } \\
\text { channel }\end{array}$ & \multicolumn{3}{|c|}{ Water channel width } & \multirow{2}{*}{ Average } \\
\cline { 2 - 4 } & $50 \mathrm{~cm}$ & $75 \mathrm{~cm}$ & $100 \mathrm{~cm}$ & \\
\hline $10 \mathrm{cn}$ & 185.33 & 171.00 & 183.53 & 179.95 \\
\hline $20 \mathrm{~cm}$ & 187.80 & 190.73 & 170.40 & 182.98 \\
\hline Average & 186.57 & 180.87 & 176.97 & \\
\hline
\end{tabular}

Numbers in the same row and column are not

significantly different $F$ test at the $5 \%$ level

The absence of interactions and significant differences with respect to panicle length and the number of grains per panicle is because genetic factors are more influential than environmental factors. Uphoof et al.,(2002) states that SRI can improve results two fold or more, because of the planting distance $(25 \mathrm{~cm} \times 25 \mathrm{~cm})$, the seedlings are replanted individually after only 7-15 days (Rozen et al., 2009). Rozen et al ., (2011) states that the SRI method can be give dry weights harvest of 10 tons/ ha. While production rice in West Sumatera only reached 4,6 tons / ha.

Table 6. Number of filled grains per panicle

\begin{tabular}{|c|c|c|c|c|}
\hline \multirow{2}{*}{$\begin{array}{c}\text { Depth of } \\
\text { water in } \\
\text { the } \\
\text { channel }\end{array}$} & \multicolumn{3}{|c|}{ Water channel width } & \multirow{2}{*}{ Average } \\
\cline { 2 - 5 } & $50 \mathrm{~cm}$ & $75 \mathrm{~cm}$ & $100 \mathrm{~cm}$ & \\
\hline $10 \mathrm{~cm}$ & 134.94 & 125.47 & 138.60 & 133.01 \\
\hline $20 \mathrm{~cm}$ & 134.20 & 144.07 & 128.53 & 135.60 \\
\hline Average & 134.58 & 134.78 & 133.57 & \\
\hline
\end{tabular}

significantly different $F$ test at the $5 \%$ level

Penggenangan lahan sawah setelah proses pengolahan lahan akan memberikan konsekuensi perubahan fisikokimia tanah. Pada kondisi tanah tergenang maka kadar oksigen dalam tanah dapat menurun drastis sampai titik nol dalam waktu kurang dari sehari sehingga mikroorganisme anaerob menjadi aktif, bahan organik akan terdekomposisi lebih lambat dan kurang sempurna (Sanchez, 1993 cit Regazzoni et al., 2013). Maka dari itu diperlukan pengeringan lahan agar oksigen dapat masuk kembali ke dalam pori tanah. Apabila tanah sawah mempunyai periode pengeringan maka mikroorganisme aerob akan aktif dalam mendekomposisi bahan organik sehingga laju dekomposisi bahan organik menjadi lebih tinggi dan mempunyai hasil yang lebih sempurna. Pengeringan selama 6 dan 9 hari pada 30 hari setelah tanam dapat meningkatkan hasil gabah sebesar dua sampai tiga kali lipat dibandingkan tanpa pengeringan (Hartatik et al., 2014 cit Regazzoni et al., 2013). 
With respect to the weight of 1000 grains of rice no significant interaction or differences were observed Table 7.

Table 7. Weight of 1.000 grains (gram)

\begin{tabular}{|c|c|c|c|c|}
\hline $\begin{array}{c}\text { Depth of } \\
\text { water in } \\
\text { the } \\
\text { channel }\end{array}$ & $50 \mathrm{~cm}$ & $75 \mathrm{~cm}$ & $100 \mathrm{~cm}$ & \multirow{2}{*}{ Average } \\
\cline { 2 - 5 } & & & & \\
\hline $10 \mathrm{~cm}$ & 22.18 & 21.42 & 22.01 & 21.87 \\
\hline $20 \mathrm{~cm}$ & 22.47 & 22.44 & 21.67 & 22.19 \\
\hline Average & 22.32 & 21.93 & 21.84 & \\
\hline
\end{tabular}

Numbers in the same row and column are not significantly different $F$ test at the $5 \%$ level

Only the depth of water in the channel had a significant effect on the yield per plot (Table 8)

Table 8. Yield ( $\mathrm{kg} / \mathrm{plot})$

\begin{tabular}{|c|c|c|c|c|}
\hline \multirow{2}{*}{$\begin{array}{c}\text { Depth of } \\
\text { water in the } \\
\text { channel }\end{array}$} & \multicolumn{3}{|c|}{ Water channel width } & \multirow{2}{*}{ Average } \\
\cline { 2 - 4 } & $50 \mathrm{~cm}$ & $75 \mathrm{~cm}$ & $100 \mathrm{~cm}$ & \\
\hline $10 \mathrm{~cm}$ & 5.27 & 3.47 & 4.17 & $4.30 \mathrm{a}$ \\
\hline $20 \mathrm{~cm}$ & 3.40 & 3.43 & 3.43 & $3.42 \mathrm{~b}$ \\
\hline Average & 4.33 & 3.45 & 3.80 & \\
\hline
\end{tabular}

Numbers in the same column followed by the same lower case letters are not significantly different, Tukey's Honest Significant Difference test at the 5\% level

It turns out that the high puddle in the channel $10 \mathrm{~cm}$ heavier grain per plot compared to $20 \mathrm{~cm}$ high puddle. Plant height and yield may be inversely related. Lack of water during the flowering phase may result in the falling of flowers and empty grains, resulting in low yields (Rismaneswati, 2006).

The initial and final weights of fish are shown in Tables 9 and 10 respectively.

Table 9. Initial weight $(\mathrm{kg})$ of Majalaya goldfish

\begin{tabular}{|c|c|c|c|c|}
\hline \multirow{2}{*}{$\begin{array}{c}\text { Depth } \\
\text { water in } \\
\text { the } \\
\text { channel }\end{array}$} & \multicolumn{3}{|c|}{ Water channel width } & \multirow{2}{*}{ Average } \\
\cline { 2 - 4 } & $50 \mathrm{~cm}$ & $75 \mathrm{~cm}$ & $100 \mathrm{~cm}$ & \\
\hline $10 \mathrm{~cm}$ & 0.10 & 0.08 & 0.09 & 0.09 \\
\hline $20 \mathrm{~cm}$ & 0.36 & 0.29 & 0.08 & 0.24 \\
\hline Average & 0.23 & 0.19 & 0.09 & \\
\hline
\end{tabular}

Numbers in the same column followed by the same lower case letters are not significantly different, Tukey's Honest Significant Difference test at the 5\% level
Table 10. The final weight of Majalaya goldfish on the minapadi-SRI method

\begin{tabular}{|c|c|c|c|c|}
\hline \multirow{2}{*}{$\begin{array}{c}\text { Depth of } \\
\text { water in } \\
\text { the channel }\end{array}$} & \multicolumn{3}{|c|}{ Water channel width } & \multirow{2}{*}{ Average } \\
\cline { 2 - 4 } & $50 \mathrm{~cm}$ & $75 \mathrm{~cm}$ & $100 \mathrm{~cm}$ & \\
\hline $10 \mathrm{~cm}$ & 0.37 & 0.30 & 0.21 & 0.29 \\
\hline $20 \mathrm{~cm}$ & 0.21 & 0.15 & 0.20 & 0.19 \\
\hline Average & 0.29 & 0.23 & 0.21 & \\
\hline
\end{tabular}

Numbers in the same column followed by the same lower case letters are not significantly different, Tukey's Honest Significant Difference test at the 5\% level

Fish yields could not be followed because the fish were eaten by pests such as birds, frogs and other fish, so the fish harvest was very small. Although weight gain occurred (in $10 \mathrm{~cm}$ of water but not $20 \mathrm{~cm}$ ) the result are not satisfactory.

\section{CONCLUSIONS}

There is no interaction between the depths of water in the channel with the width of the channel. Ten $\mathrm{cm}$ of water in the channel is better for growth and yield of IR42 varieties of rice. The width of the ditch did not affect the growth and yield of IR42 varieties, but the 50 $\mathrm{cm}$ trench width is better.

\section{ACKNOWLEDGMENTS}

Thank you to Directorat Research and Community Service Haigher Education for funding this research and to Research Institutions and Community Service Andalas University who has facilitated this research. We would like to extend our gratitude to all those who have assisted with this research. The authors received assistance improving the reporting of the findings and the use of English in and organization of the text.

\section{REFERENCES}

[1] Berkelaar, D. 2001. System of Rice Intensification-SRI: Some can provide more. ECHO Newsletter Development Notes, Inc. 17.391 Durrance Rd. North FtMyers FI.33917 USA.

[2] Berkelaar, D. 2002. The system of Rice Intensification (SRI): Few can give more. ECHO Development Note Bulletin, January 2001. ECHO Inc. 17391 Durrance Rd. North FtMyers FI.33917 USA.

[3] Dedatta, SK 1981. Principles and Practices of Rice Production . John WS editor. Canada (CA). P 618.

[4] Diodenha, A. 2011. Environmental Perception of Purwasari Village Farmers, Kec. Dramaga, Kab. Bogor Against Application of Intensification Technology of Mina Padi (INMIDI). Essay. Bogor Agricultural Institute. 
[5] Dzomeku, I.K., E. N. K. Sowley and I. S. Yussif. 2016. Evalution of system of rice intenfication (SRI for enhanced rice (Oryza sativa L). Production in the Guinea Savannah one of Ghana. Current Agriculture Research Journal. 4 (1) : 84-93.

[6] Kasli and Effendi, AR. 2011. The Influence of High Growth in Rice Fields (Oryza sativa L.) in Pot. Straw Journal. Vol. 4.no.3.

[7] Kawano, N., Ito, O. \& Sakagami, J. 2009. Morpho-logical and physiological responses of rice seedlings to complete submergence (flash flooding). Annals of Botany. 103: 161-169. doi: 10.1093 / aob / men 171.

[8] Kumar, M. R., R. P. Rao, N. Somasekhar, K. Surekha. 2013. SRI-A method for sustainable intensification of rice production with enhanced water productivity. Agrotechnology. 2-6

[9] Nuryati, L., B. Waryanto., Noviati, and R. Widaningsih. 2015. Outlook: Agricultural Commodity Subsector of Food Crops. Center for Agricultural Data and Information Systems. Ministry of Agriculture. 103 pp.

[10] Ramli, M. 2010. Development of aquaculture and its contribution in the agricultural sector in the economy of Lima Puluh Kota District, West Sumatera.Journal of Aquatic Science. 8.no.1

[11] Regazzoni, O., Y. Sugito dan A. Suryanto. 2013. Sistem irigasi berselang (Intermittent irrigationpadi) pada budidaya (Oryza sativa L) varietas Inpari-13 dalam pola SRI (System Of Rice Intensification). Jurnal Produksi Tanaman. 1(2) : 42-46

[12] Rismaneswati. 2006. Influence Terracottem, Compost and Mulch Straw on Soil Physical Properties, Growth and Production of Soy (Glycine max L. Merr) on Alfisols Tamalanrea. Journal of Science \& Technology, August 2006, Vol. 6 No. 2: 81-86.

[13] Rozen, N. 2008. Mechanism of tolerating rice fields for weeds in the SRI (System of Rice Intensification) method. University of Graduate Programs Dissertation Program.

[14] Rozen, N, M. Kasim, M. Rahman and I. Suliansyah. 2009. The mechanism of rice crops that competes with weeds in SRI. Journal of Straw. Vol. 2 (3) September-December.

[15] Rozen, N., Afrizal and Sabrina. 2011. Improvement potency farmers through technology transfer from system agriculture SRI in Padang City. Report End Devotion Community Program IBW. DRPM Dikti.

[16] Stoop,W.A., N. Uphoff and A. Kassam. 2002. A review of agricultural research issues raised by the system of rice intensificstion (SRI) from Madagascar : opportunities for improving farming system for resource-poor farmers. Agricultural Systems. $71: 249-274$

[17] Uphoff, N, KSYang, P.Gypmantasiri, K.Prinz, and H.Kabir. 2002. The system of rice intensification (SRI) and its relevance for food security and natural resource management in Southeast Asia. International Symposium Sustaining Food Security and Managing Natural Resource in Southeast Asia-Challenges for the 21 st Century. January 8-11, 2002 at Chiang Mai, Thailand. (Klaus.prinz@gmx.net ); Advisor, Metta
Development Foundation, Yangoon, Myanmar (h kabir3@yahoo.com). 13 p.

[18] Veeramani, PRD. Singh and K. Subrahmaniyan. 2012. Study of phyllochron system of rice intensification technique (SRI). Agricultural Science Risearch Journal. Vol. 2 No.6 pp.329-334

[19] Vergara. 1976. Physiological and Morphological Adaptability.

https://www.yumpu.com/en/document/view/55620621/ver gara-1976-physiological-and morphological-adaptabilityof-ri. Diakses tanggal 12 April 2018. 